\title{
Should Asymptomatic and Low-Risk Individuals be Tested for SARS-CoV-2?
}

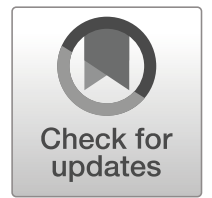

J Gen Intern Med 35(9):2810-2

DOI: $10.1007 / \mathrm{s} 11606-020-06000-\mathrm{Z}$

(c) The Author(s) 2020

\section{INTRODUCTION}

Because people with asymptomatic SARS-CoV-2 infections are an important source of transmission, widespread testing has the potential to identify and isolate such individuals, quarantine their contacts, and prevent further spread. However, testing for a condition in a group with low disease prevalence may lead to numerous false positive results. This study quantifies the tradeoff between reducing transmission by true positives and unnecessary isolation and quarantine due to false positives.

\section{METHODS}

The impact of testing was modeled based on the following parameters: $1 \%$ prevalence of active infection, test sensitivity $90 \%$ and specificity $95 \%$, reproduction number 0.9 , and 5 contacts per case. ${ }^{1-5}$ Because performance of SARS-CoV-2 tests is not well established, the values that correspond to PCR-based tests for other respiratory viral infections were used. $^{2,3}$ The reproduction number $R$ is the median value in the USA. ${ }^{4}$ Because individuals with positive test results will be instructed to isolate, $R$ following a positive test was assumed to decrease to $0.1 .^{5}$ The number of people subsequently infected by each infected case disease was calculated using the formula $R+R^{2}+R^{3}+\ldots=1 /(1-R)-1$ when $R<1$. For $R=$ 0.9 , this sum of 9.0 represents the number of new infections in a transmission chain and was applied to individuals with false negative results and to infected individuals who were not tested. The corresponding sum for a true positive case is 1.0 , which assumes a reproduction number of 0.1 for the first transmission and 0.9 for subsequent transmissions.

\section{RESULTS}

In the base case, testing will result in 5.5 times more false positive than true positive results (Table 1). Testing will result

Received May 28, 2020

Accepted June 15, 2020

Published online June 24, 2020 in 72,000 fewer infections. Of the 351,000 people who will be isolated or quarantined, a substantial majority $(297,000)$ will be isolated or quarantined because of false positive tests. With a higher prevalence of active infection, there will be 180,000 fewer infections, but a large number of people will still need to be isolated or quarantined. A highly specific test yields fewer false positives. About half $(54,000)$ of the 113,400 people who must be isolated or quarantined will be because of true positive tests. A test that is both highly specific and sensitive will also greatly reduce the number of false negatives. At very high levels of test specificity, the number of people needed to isolate or quarantine (NNIQ) per infection prevented decreases and is minimally affected by variations in test sensitivity (Fig. 1).

\section{DISCUSSION}

This analysis indicates that policy makers should avoid instituting mass testing of asymptomatic and low-risk individuals until a test with very high specificity becomes available. Determining test specificity will be challenging in the absence of a gold standard that definitively establishes the presence of absence of SARS-CoV-2. There are several possible approaches to clarify the magnitude of false positive results. A second test can be performed, preferably from a different manufacturer, to determine if it is negative. A serological test can be performed at a later date to determine if antibodies to SARS-CoV-2 develop as expected after infection. Individuals can also be followed over time to determine if they subsequently develop COVID-19 symptoms.

Several limitations must be considered in interpreting these results. The results do not apply to testing of symptomatic or high-risk groups. The actual values of model parameters have not been well established. The analyses assume that these parameters do not change over time. The number of contacts per infected individual (and therefore the number quarantined) may be higher or lower than the estimate used in these analyses. For example, the number of people who need to quarantine would be lower if the same individual is the contact of more than one infected person. Alternatively, much higher numbers of contacts, i.e., 10-30 per case, have been reported in some settings. ${ }^{6}$ As a result, it will be important to continue some social isolation restrictions to limit the number of people who must be quarantined. In addition, it is unclear whether contacts who have already recovered from COVID-19 or are 
Table 1 Simulated Results of One-Time Testing of 1 Million Asymptomatic and Low-Risk Individuals for SARS-CoV-2

\begin{tabular}{|c|c|c|c|c|}
\hline & Base case & $\begin{array}{l}\text { Higher prevalence of } \\
\text { active infection }\end{array}$ & Better test specificity & $\begin{array}{l}\text { Better test sensitivity } \\
\text { and specificity }\end{array}$ \\
\hline Model parameters & $\begin{array}{l}\text { - Prevalence of active infection: } 1 \% \\
\text { - Test sensitivity, specificity: } 90 \% \text {, } \\
95 \% \\
\text { - Reproduction number: } 0.9(0.1 \\
\text { after positive test) } \\
\text { - Contacts per case: } 5\end{array}$ & $\begin{array}{l}\text { - Prevalence of active } \\
\text { infection: } 2.5 \% \\
\text { - Test sensitivity, } \\
\text { specificity: } 90 \%, 95 \% \\
\text { - Reproduction number: } \\
0.9 \text { (0.1 after positive test) } \\
\text { - Contacts per case: } 5\end{array}$ & $\begin{array}{l}\text { - Prevalence of active } \\
\text { infection: } 1 \% \\
\text { - Test sensitivity, } \\
\text { specificity: } 90 \%, 99 \% \\
\text { - Reproduction number: } \\
0.9(0.1 \text { after positive test }) \\
\text { - Contacts per case: } 5\end{array}$ & $\begin{array}{l}\text { - Prevalence of active } \\
\text { infection: } 1 \% \\
\text { - Test sensitivity, } \\
\text { specificity: } 99 \%, 99 \% \\
\text { - Reproduction number: } \\
0.9 \text { (0.1 after positive test) } \\
\text { - Contacts per case: } 5\end{array}$ \\
\hline Results of testing & $\begin{array}{l}\text { - True positive: } 9000(0.9 \%) \\
\text { - False positive: } 49,500(5.0 \%) \\
\text { - True negative: } 940,500(94.1 \%) \\
\text { - False negative: } 1000(0.1 \%)\end{array}$ & $\begin{array}{l}\text { - True positive: } 22,500 \\
(2.3 \%) \\
\text { - False positive: } 48,750 \\
(4.9 \%) \\
\text { - True negative: } 926,250 \\
(92.6 \%) \\
\text { - False negative: } 2500 \\
(0.3 \%)\end{array}$ & $\begin{array}{l}\text { - True positive: } 9000 \\
(0.9 \%) \\
\text { - False positive: } 9900 \\
(1.0 \%) \\
\text { - True negative: } 980,100 \\
(98.0 \%) \\
\text { - False negative: } 1000 \\
(0.1 \%)\end{array}$ & $\begin{array}{l}\text { - True positive: } 9900 \\
(1.0 \%) \\
\text { - False positive: } 9900 \\
(1.0 \%) \\
\text { - True negative: } 980,100 \\
(98.0 \%) \\
\text { - False negative: } 100 \\
(0.01 \%)\end{array}$ \\
\hline $\begin{array}{l}\text { Transmission chain of } \\
\text { infection if testing }\end{array}$ & $\begin{array}{l}\text { - From } 9000 \text { true positives: } 9000 \\
\text { new cases } \\
\text { - From } 1000 \text { false negatives: } 9000 \\
\text { new cases }\end{array}$ & $\begin{array}{l}\text { - From } 22,500 \text { true } \\
\text { positives: } 22,500 \text { new } \\
\text { cases } \\
\text { - From } 2500 \text { false } \\
\text { negatives: } 22,500 \text { new } \\
\text { cases }\end{array}$ & $\begin{array}{l}\text { - From } 9000 \text { true } \\
\text { positives: } 9000 \text { new cases } \\
\text { - From } 1000 \text { false } \\
\text { negatives: } 9000 \text { new } \\
\text { cases }\end{array}$ & $\begin{array}{l}\text { - From } 9900 \text { true } \\
\text { positives: } 9900 \text { new cases } \\
\text { - From } 100 \text { false } \\
\text { negatives: } 900 \text { new cases }\end{array}$ \\
\hline $\begin{array}{l}\text { Transmission chain of } \\
\text { infection if no testing }\end{array}$ & $\begin{array}{l}\text { - From } 10,000 \text { infected individuals: } \\
90,000 \text { new cases }\end{array}$ & $\begin{array}{l}\text { - From 25,000 infected } \\
\text { individuals: } 225,000 \text { new } \\
\text { cases }\end{array}$ & $\begin{array}{l}\text { - From 10,000 infected } \\
\text { individuals: } 90,000 \text { new } \\
\text { cases }\end{array}$ & $\begin{array}{l}\text { - From 10,000 infected } \\
\text { individuals: } 90,000 \text { new } \\
\text { cases }\end{array}$ \\
\hline $\begin{array}{l}\text { Isolation and } \\
\text { quarantine due to } \\
\text { testing }\end{array}$ & $\begin{array}{l}\text { - Isolation: } 58,500 \text { positive test } \\
\text { results } \\
\text { - Quarantine: } 292,500 \text { contacts }\end{array}$ & $\begin{array}{l}\text { - Isolation: } 71,250 \\
\text { positive test results } \\
\text { - Quarantine: } 356,250 \\
\text { contacts }\end{array}$ & $\begin{array}{l}\text { - Isolation: } 18,900 \\
\text { positive test results } \\
\text { - Quarantine: } 94,500 \\
\text { contacts }\end{array}$ & $\begin{array}{l}\text { - Isolation: } 19,800 \\
\text { positive test results } \\
\text { - Quarantine: } 99,000 \\
\text { contacts }\end{array}$ \\
\hline $\begin{array}{l}\text { Overall effect of } \\
\text { testing }\end{array}$ & $\begin{array}{l}\text { - 72,000 fewer infections } \\
\text { - } 351,000 \text { people isolated or } \\
\text { quarantined } \\
\text { - } 4.9 \text { number of people needed to } \\
\text { isolate or quarantine (NNIQ) per } \\
\text { infection prevented }\end{array}$ & $\begin{array}{l}-180,000 \text { fewer infections } \\
\text { - } 427,500 \text { people isolated } \\
\text { or quarantined } \\
\text { - } 2.4 \text { NNIQ }\end{array}$ & $\begin{array}{l}\cdot 72,000 \text { fewer infections } \\
\text { - } 113,400 \text { people isolated } \\
\text { or quarantined } \\
\text { - } 1.6 \text { NNIQ }\end{array}$ & $\begin{array}{l}-79,200 \text { fewer infections } \\
\text { - } 118,800 \text { people isolated } \\
\text { or quarantined } \\
\text { - } 1.5 \mathrm{NNIQ}\end{array}$ \\
\hline
\end{tabular}

known to have antibodies need to be quarantined. In contrast to more complex and less transparent models, these parame- ters and accompanying calculations can be easily modified for other scenarios and updated as the pandemic evolves.

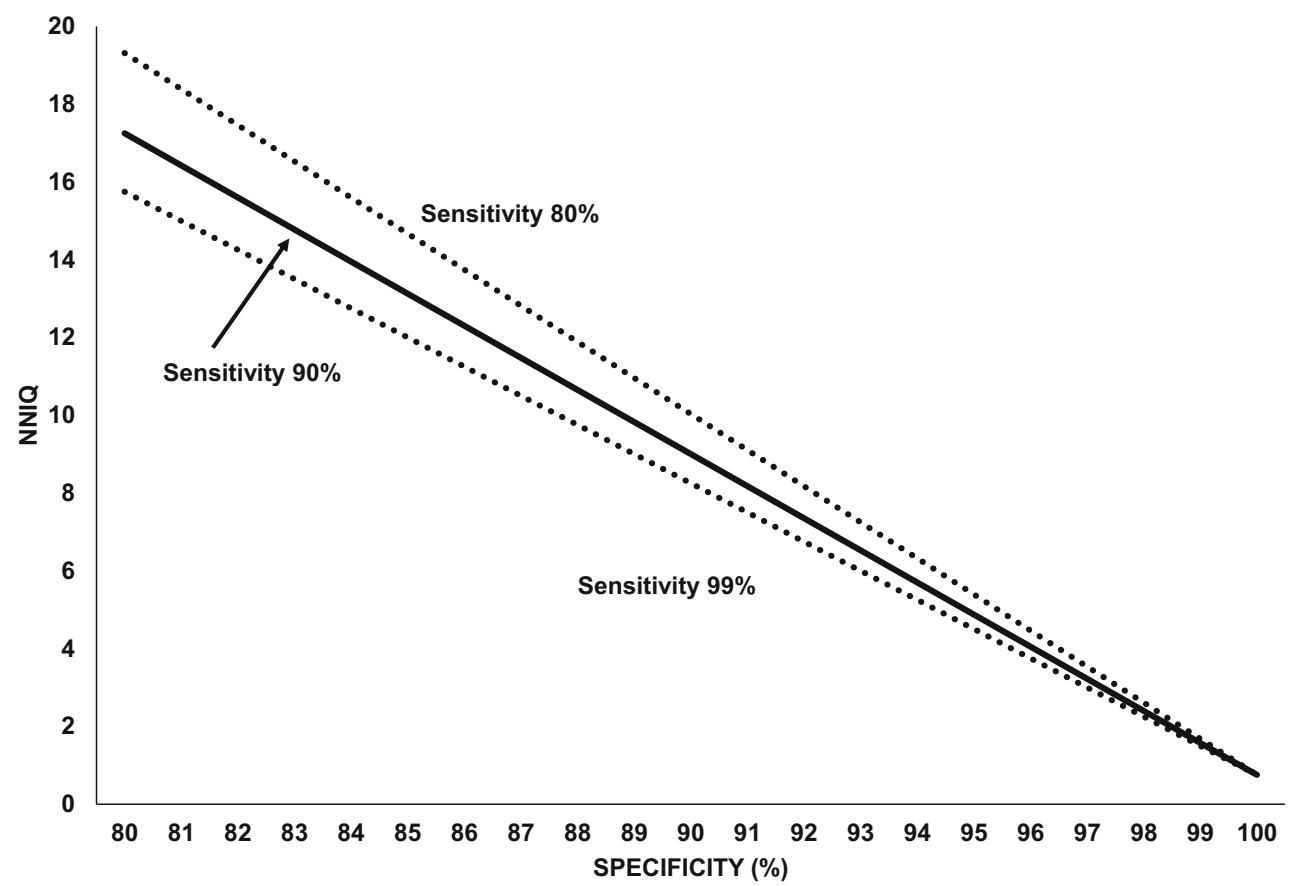

Figure 1 The number of people needed to isolate or quarantine (NNIQ) to prevent one infection as a function of test performance. From top to bottom, the three lines represent test sensitivity of $80 \%, 90 \%$, and $99 \%$. 
Ashwini R. Sehgal, $M D^{1}$

${ }^{1}$ Center for Reducing Health Disparities, Case Western Reserve University, 2500 Metro Health Drive, Cleveland, OH, USA

Corresponding Author: Ashwini R. Sehgal, MD; Center for Reducing Health Disparities, Case Western Reserve University, 2500 Metro Health Drive, Cleveland, OH, USA (e-mail: sehgal@case.edu).

Funding information This study was supported by grant MD002265 from the National Institutes of Health.

Open Access This article is licensed under a Creative Commons Attribution 4.0 International License, which permits use, sharing, adaptation, distribution and reproduction in any medium or format, as long as you give appropriate credit to the original author(s) and the source, provide a link to the Creative Commons licence, and indicate if changes were made. The images or other third party material in this article are included in the article's Creative Commons licence, unless indicated otherwise in a credit line to the material. If material is not included in the article's Creative Commons licence and your intended use is not permitted by statutory regulation or exceeds the permitted use, you will need to obtain permission directly from the copyright holder. To view a copy of this licence, visit http://creativecommons. org/licenses/by/4.0/.

\section{REFERENCES}

1. TRACE-COVID-19 project. Available at https://trace.oregonstate.edu Accessed May 28, 2020.

2. Kokkinakis I, Selby K, Favrat B, Genton B, Cornuz J. COVID-19 diagnosis: clinical recommendations and performance of nasopharyngeal swab PCR. Rev Med Suisse. 2020;16:699-701.

3. Basile K, Kok J, Dwyer DE. Point-of-care diagnostics for respiratory viral infections. Expert Rev Mol Diagn. 2018;18:75-83.

4. Rt COVID-19. Available at https://rt.live Accessed May 28, 2020.

5. Jarvis CI, Van Zandvoort $\mathbf{K}$, Gimma A, et al. Quantifying the impact of physical distance measures on the transmission of COVID-19 in the UK. BMC Med. May 7, 2020. doi:https://doi.org/10.1186/s12916-020-015978

6. Cheng HY, Jian SW, Liu DP, Ng TC, Huang WT, Lin HH. Contact tracing assessment of COVID-19 transmission dynamics in Taiwan and risk at different exposure periods before and after symptom onset. JAMA Int Med. May 1, 2020. doi:https://doi.org/10.1001/jamainternmed.2020.2020

Publisher's Note: Springer Nature remains neutral with regard to jurisdictional claims in published maps and institutional affiliations. 